\title{
Is Giriama Traditionalism a Religion? Negotiating Indigenous African Religiosity in 'Interfaith' Cooperation in Coastal Kenya
}

\author{
Erik Meinema \\ Department of Philosophy and Religious Studies, Utrecht University, Utrecht \\ e.h.meinema@uu.nl
}

\begin{abstract}
This article explores how Giriama elders represent their 'traditional religion' (dini ya jadi) through 'interfaith' cooperation with Christians and Muslims in the coastal Kenyan town of Malindi. Based on extensive ethnographic research, the article analyses how Giriama Traditionalism relates, in complex and ambivalent ways, to normative assumptions and ideals with regard to what religion entails, and in turn how Giriama elders seek recognition as representatives of a religion in this setting. Such claims are made in a context where Christians, Muslims, and state actors sometimes doubt whether Giriama Traditionalism is worthy of being called a 'religion' at all. The article demonstrates that although in the context of interfaith cooperation Christianity, Islam, and 'Traditionalism' are formally recognized as equal religions, this does not necessarily create a level playing field. Instead, it requires Giriama elders to appropriate terms, norms, and ideals that are not necessarily of their own making in order for Giriama Traditionalism to be recognized as a religion. Through this analysis, the article aims to contribute to theoretical debates about religious diversity in African contexts by demonstrating how negotiations about what properly counts as (good) religion in coastal Kenya are deeply informed by the copresence of Christianity, Islam, and indigenous African religiosity in one religious field.
\end{abstract}

\section{Keywords}

Indigenous African Religious Traditions - Interfaith - Religious Coexistence - Islam Christianity - Coastal Kenya 


\section{Introduction}

Sisi kama wazee wa Kaya, tumeweza kushirikishwa katika muungano wa Coast Interfaith Council of Clerics kwa sababu pia sisi nasi tuko na dini, ... dini yetu ni dini ambayo inaabudu Mungu, ile Mmoja kila mtu anaabudu.

We as Kaya elders have been able to become involved in the cooperation of the Coast Interfaith Council of Clerics, because we too have a religion, ... our religion is a religion that worships God, the One that everyone worships.

Quotation of MADCA elder (CICC 2019)

In November 2016 I visited the Mekatilili wa Menza cultural centre of the Malindi District Cultural Association (MADCA) for the first time. MADCA is an organization that aims to revive and promote the religion and culture of the Giriama ethnic group in the coastal Kenyan town of Malindi. Its cultural centre is named after the Giriama heroine Mekatilili wa Menza, who resisted British imperial demands during the Giriama uprising of 1914 (Brantley 1973, 1979; Carrier and Nyamweru 2016). Malindi is an ethnically and religiously pluriform town where the Giriama live together with Swahili Muslims and Christians from various ethnic backgrounds. This religious diversity is clearly visible and audible in the Mbuzi Wengi area of Malindi, where MADCA's centre is located within the audible range of the amplified call to prayers of a mosque, and in the immediate proximity of four churches that frequently use PA systems for loud worship services and prayer meetings.

The Mekatilili wa Menza centre functions as a place where members of MADCA hold meetings; engage in dancing, drumming, and singing; and display Giriama culture. One of the Giriama elders who actively participates in MADCA received me, and showed me around the palm-leaf-fenced compound of the open-air centre. Within the compound there was a traditional grass-thatched beehive-shaped Giriama house, a meeting space, and a small palm-thatched hut (sing. kigojo) in which several vigango (sing. kigango) and makoma (sing. koma) are placed. Vigango and makoma are wooden posts that the Giriama use to engage with deceased ancestors. The more elaborate vigango are used in relation to people who are initiated in the Gohu society (Udvardy 2013). ${ }^{1}$ During our meeting the Giriama elder explained that Muslims and Christians incorrectly understood Giriama engagement with vigango and makoma as idolatrous, since they misinterpret Giriama people as adoring the vigango and makoma themselves. In defence, he compared Giriama engagement with ancestors to the mediating role of saints in Catholic prayer, stressing that during prayer ancestors function as intermediaries between their descendants 
and God. During our conversation the Giriama elder complained that Muslims and Christians also reject various other features of Giriama tradition, such as Giriama dress, medicine, and ways of educating youth. Responding to such accusations, he pointed to the moral benefits of what he called 'African Traditional Religion': it teaches youth to dress decently, adhere to sexual morals, and respect the authority of elders.

During the extensive conversations that I had with various Giriama elders at MADCA, they frequently pointed to similarities when they compared Giriama ideas and practices to Islamic and Christian ones. MADCA elders arguably focus on these similarities to strengthen the idea that Giriama Traditionalism is a religion that is similar and equal to Islam and Christianity. This claim is relevant because some Muslims and Christians in Malindi doubt whether Giriama Traditionalism is worthy of being called a 'religion' at all. Furthermore, recognizing it as a religion also allows MADCA elders access to cooperation with the Coast Interfaith Council of Clerics (CICC). In this civil society organization (CSO) MADCA elders work with Muslim and Christian clerics as they represent their 'dini ya jadi' (literally 'religion of tradition'), for which I use the term 'Giriama Traditionalism' here. ${ }^{2}$

Such interfaith cooperation between Muslims, Christians, and Traditionalists relies on a conception of the term 'religion' that assumes both the multiplicity and the equality of various religions in ways similar to the secular Kenyan constitution, which guarantees freedom of religion and state neutrality toward various religions. Interfaith civil society engagement also mobilizes various religions to work toward peace, interfaith harmony, and particular development goals. In this way, it introduces normative assumptions about what (good) religion is or ideally should be, to which various religions are expected to adhere. This article uses the cooperation between MADCA and CICC as a case study to analyse how Giriama Traditionalism relates, in complex and ambivalent ways, to such normative assumptions and ideals with regard to religion, and the strategic ways in which MADCA elders seek recognition as representatives of a religion in this setting. Thus rather than applying an overarching theory of religion to determine whether or not Giriama Traditionalism constitutes a religion, this article explores how various actors, in particular the Giriama elders and Muslim and Christian clerics who cooperate in CICC, conceptualize the category of religion and position themselves in relation to it. Through such an analysis, the article aims to contribute to theoretical debates about religious diversity in African contexts by demonstrating how negotiations about what properly counts as (good) religion in coastal Kenya are deeply informed by the historical and contemporary copresence of indigenous African religiosity, Christianity, and Islam in one religious field (Janson and Meyer 2016), in 
which, in the Kenyan case, Christianity especially has often played a predominant role. In particular, the article shows that although the interfaith cooperation within CICC formally recognizes Christianity, Islam, and Traditionalism as equal religions, this recognition does not necessarily create a level playing field. Instead, it requires that Giriama Traditionalists appropriate terms, norms, and ideals that are not necessarily of their own making in order to be recognized as representatives of a religion (De Witte 2010, 2015).

This article is structured as follows. After a brief discussion of religious plurality in Malindi, I discuss how indigenous African religious traditions usually occupy only marginal positions within postcolonial Kenyan society as 'religious freedom misfits' (Hackett 2015, 91). This term has been coined by Rosalind Hackett to emphasize that indigenous African religious traditions often fail to be recognized as a religion in many postcolonial African states, and consequently struggle to receive constitutional protection, public recognition, and equal treatment under the law. I subsequently analyse how cooperation between CICC and MADCA features often-tacit contestations about the question of whether Giriama Traditionalism can be seen as a religion that is equal to Christianity or Islam. Finally, I discuss four strategies through which Giriama elders aim to strengthen the idea that Giriama Traditionalism should be recognized as a religion. However, these strategies also require that they represent Giriama Traditionalism in ways that align with Islamic and Christian conceptions of religion and morality, which implicitly inform interfaith cooperation within CICC.

Malindi is located on the East African coast, where Islam has a long historical presence. As a primarily urban phenomenon, Islam stood in connection to wide networks of Indian Ocean trade, and from the early sixteenth century onward European exploration and expansion. In this context, the term 'Swahili' has come to denote Muslims who inhabit the East African coast (as a highly flexible ethnic label), their language Kiswahili, and their coastal culture (Gearhardt and Giles 2013). Christianity only made a lasting impact in the areas of present-day Kenya under British imperialism (1895-1963) particularly among many interior populations (Chidongo 2012). As a result, Kenya currently is a Christian-majority country with a significant Muslim minority. Many Kenyan Muslims continue to live in coastal towns such as Mombasa, Malindi, and Lamu. In the rural hinterlands around these towns other coastal populations often form the majority, some of whom collectively coined their 
identity as 'Mijikenda' from around the 1940s onward (Willis 1993). In and around Malindi the Giriama are the most numerous Mijikenda subgroup.

In precolonial times Swahili Muslims often referred to non-Muslim coastal populations as 'infidels' (makafiri) or 'bush people' (wanyika) (Sperling 1988, 43). Despite such derogative attitudes, there also was considerable fluidity, trade, cooperation, and interdependence between Swahili Muslims and various hinterland populations (Spear 1978; McIntosh 2009; Willis 1993). Under British imperialism, however, colonial regulations solidified ethnic boundaries on the coast since British officials only recognized Arab and Swahili land claims and excluded the Mijikenda. After the British completely abolished slavery in 1907, Arab slave plantations were severely undermined. British administrators subsequently tried to restructure the coastal economy by mobilizing 'African' coastal populations, including the Giriama, for plantation and wage labour (Brantley 1973; Cooper 1980). Since the British generally did not succeed in this aim due to fierce Giriama resistance, they created a situation in which Arab and Swahili landowners did not have a sufficient labour force to work their land, while the Mijikenda who worked the land did so as squatters on land that they did not own (Cooper 1980; McIntosh 2009). This situation significantly hindered the economic and agricultural prosperity of coastal areas, and precolonial modes of economic production and exchange were severely undermined (Brantley 1973; Cruise O’Brien 1995).

This economic impasse has continued in postcolonial times when coastal Muslims and Mijikenda from various religious backgrounds repeatedly complained about their marginalization in relation to 'upcountry' Christians in terms of education, economics, access to land, and government representation (McIntosh 2009; Cruise O'Brien 1995; Kresse 2009). Such feelings increased after many Christians from upcountry settled in coastal towns to work in tourism, business, or the government. Many Giriama in Malindi, however, occupy marginal economic positions in relation to Arab and Swahili Muslims as well (McIntosh 20o9; Mkangi 1995). Although some Giriama achieve political and economic success, most Giriama in Malindi live in the outskirts of Malindi town where they struggle to procure a livelihood through low-wage labour, driving motorcycle taxis, or subsistence farming.

The economically marginal position of many Giriama is connected to a long history in which Muslims, Christians, and state actors have denigrated the Giriama and their traditional practices as backward, idolatrous, and connected to witchcraft (McIntosh 2004, 2009; Brantley 1979; Nyamweru 2013; Parkin 1991; Kresse 2019). Many Giriama have internalized such judgments, and mostly self-identify as Christians and sometimes as Muslims in Malindi town (McIntosh 2004, 2005a, 2009). In particular, Pentecostal-oriented Christianity 
has recently made an impact among many Giriama since Pentecostalism, like Giriama Traditionalism, recognizes a multitude of malicious spiritual forces against which the Holy Spirit provides protection (Parkin 1991; Meyer 1999). Other Giriama struggle to achieve upward mobility and try to do so by attempting to cross increasingly sharp ethno-religious boundaries between the Giriama and Swahili by becoming Muslims (McIntosh 2009). Yet Giriama who self-identify as Muslims are often not fully accepted as such by Swahili Muslims, who continue to view the Giriama as their civilizational and religious inferiors (McIntosh 2009, 2005a, 2004; Parkin 1972).

Some Giriama in Malindi self-identify as Traditionalists even though many Muslims and Christians look down on Giriama Traditionalism. However, even when Giriama self-identify as Christians or Muslims, they often continue to secretly participate in Giriama ritual practice, for example by visiting waganga, a Kiswahili term that is commonly translated into English as 'traditional healers' by those who visit them but as 'witchdoctors' by those who condemn them (Tinga 1998). Like other Giriama, waganga may self-identify as Christians, Muslims, or Traditionalists. For example, Giriama waganga who self-identify as Muslims often incorporate Islamic elements in their healing and divination practices (Parkin 1970, 1989; McIntosh 2004, 2009). Giriama thought recognizes that ritual practices can be used for beneficial (uganga) and malicious ends (uchawi) (Parkin 1991). However, many Muslims and Christians look down on the practices of all waganga as traditional and connected with witchcraft (uchawi), even though non-Giriama Christians sometimes visit waganga themselves (Parkin 1970, 1972). Furthermore, many Swahili Muslims visit their own religious specialists who engage the spiritual realm for healing and divination purposes, although these Swahili practitioners often prefer to call themselves mwalimu wa kitabu (teacher of the book) or tabibu (healer) to distinguish themselves from Giriama waganga (McIntosh 20og).

Similar to many other African postcolonial states in Africa and beyond, the Kenyan state constitutionally guarantees freedom of worship and state neutrality toward various religions (Leatt 2015). However, indigenous African religious traditions frequently occupy positions as 'religious freedom misfits', which means that they have an ambiguous status as either religion or culture, are often associated with witchcraft, and need to struggle for public recognition and equal treatment under the law (Hackett 2015, 91; 2011). Focusing on the Kenyan context, law scholars John Osogo Ambani and Ochieng Ahaya 
similarly argue that indigenous African religiosity often remains unrecognized and excluded within Kenyan law, which largely builds on Christian morality and British common law introduced under colonialism. In this situation, 'apart from the Christian faith, customs, laws, and values consistent with it, any other religion or custom is certain to find the Kenyan legal system not very hospitable' (Ambani and Ahaya 2015, 53).

Contestations over indigenous African religiosity find their roots in colonialism. Already at the Berlin Conference (1884-1885), European empires agreed that 'freedom of conscience and religious toleration [would be] expressly guaranteed to the natives, no less than to subjects and foreigners' (Chidester 2014, 19). Colonial administrators thus needed to operationalize ideas about what properly constitutes a religion in order to determine to whom and what this 'freedom of conscience and religious toleration' extends. Hence the question of how the colonial administration, in their interactions with various Africans, missionaries, and scholars, operationalized and demarcated the concept of religion had strong political implications from the outset of colonial times.

The task of identifying and demarcating African religiosity was complicated, and was closely connected with colonial statecraft (Ciekawy 1998). Scholars have noted that many African languages that the colonial powers encountered initially had no direct equivalent for the term 'religion' (Brenner 1989). Except for the Kiswahili term 'dini' (religion, from Arabic, dinn), used by coastal Muslims to denote Islam, this was also generally the case in British East Africa (Peterson 2002; Kenyatta 1938; Sperling 1988; Mazrui 2016). To solve this problem the British categorized various African practices and beliefs under the rubrics of partly overlapping English terms such as 'religion', 'tradition', and 'witchcraft', while submitting these categories to juridical regulation. Practices considered to be religious were tolerated if they were not subversive toward British rule (Wipper 1977). The category of tradition functioned to signal African ideas and practices that were considered valuable, but grounded in the past and hence behind and distinct from what was considered to be Western, modern, and civilised (Meyer 2015). Other African beliefs and practices were seen as 'repugnant to justice and morality' and criminalized (Cotran 1983). Besides polygamy and female circumcision, this category also included African practices and concerns related to the use of spiritual forces for malicious ends. Such practices were designated with the English term 'witchcraft' and criminalized under the Witchcraft Act of 1925, which remains in place largely unaltered to this day (Ciekawy 1998). The colonial category of witchcraft sometimes partly overlapped with indigenous conceptualizations of malicious engagement with the spiritual realm. Nevertheless, scholars have noted that British administrators also frequently criminalized African practitioners, practices, and objects 
that in the eyes of Africans themselves were thought to engage spiritual forces for beneficial ends (Luongo 2011; Ciekawy 1998; Kenyatta 1938; Tinga 1998; Harrington 2018).

The British also used the term 'witchcraft' to demonise political opposition to their rule. While British officials often imagined witchcraft to be a primitive superstition that they expected to disappear under modernization, they also thought it to be powerful when they feared it was used against them (Brantley 1979; Luongo 2011). For example, after many Giriama swore a proscriptive oath (kiraho) of noncompliance against the British during the Giriama uprising in 1914, the British understood oaths as witchcraft, contrary to Giriama conceptualizations, and after they violently repressed Giriama resistance demanded that the Giriama swear oaths of loyalty (Brantley 1973).

Ambiguities and contestations around indigenous African religiosity continue in postcolonial Kenya, in which these religions often occupy positions as religious freedom misfits. Makau Mutua (1999) argues that the independence constitution of 1963 guarantees freedom of religion, describing it as 'the freedom to change religion or belief, and freedom, either alone or in community with others, and both in public and private, to manifest and propagate his religion or belief in worship, teaching, practice and observance'. However, religious freedom is limited to the interests of public morality and health. Since many African independence constitutions were based on European examples, Mutua (1999) suspects that these limitations primarily aim to exclude 'elements of indigenous African religions', while the provision to protect the right to 'propagate' one's religion (Art. 78) favours Christianity and Islam since they both have proselytizing characteristics.

Mutua's fears for the exclusion of indigenous African religiosity have been confirmed during postcolonial times. Political elites continue to openly condemn the belief in witchcraft, and encourage Kenyans to overcome it to enable development (Kresse 2019; Parkin 1991; Smith 2008). Furthermore, government institutions continue to associate indigenous African religion and culture with witchcraft. In 2014 the Kenya Law Reform Commission (KLRC) explicitly discussed the question whether witchcraft could be seen as 'a form of religion' (KLRC 2014). The KLRC asked this question to determine whether practices and beliefs denoted by the term 'witchcraft' should be protected under the provision of freedom of religion, instead of criminalized under the Witchcraft Act. The KLRC argued that there is a 'thin line that separates witchcraft from religion'. The KLRC also referred to the assertion of Émile Durkheim that religion is 'something eminently social', and argued that witchcraft is not social but depends more on private belief. Furthermore, the KLRC claimed that witchcraft 'sharply differs' from religion, in that witchcraft can be used for harm, 
while religion 'brings out virtues and ensure one's spiritual wellbeing'. Religion is also considered the 'glue which together with the law tightens the social fabric of any population'. The KLRC subsequently linked witchcraft to 'African cultures', arguing that they have a 'history of endorsing witchcraft from time immemorial' (KLRC 2014).

Although the KLRC has left open the possibility that forms of indigenous African religiosity exist that deserve state acknowledgement and constitutional protection, the assertion that witchcraft is somehow close to religion and that it is connected to African culture demonstrates that the KLRC finds it more difficult to identify and acknowledge indigenous African religious traditions as social and virtuous than other religions, such as Christianity or Islam. Furthermore, state actors often remain suspicious of movements that draw on indigenous African religious traditions, including Mijikenda Traditionalism, because they fear these movements may engage in demonic activities that undermine the political status quo (Ciekawy 2009; Mitsanze and Giles 2013). ${ }^{3}$ For example, several Giriama elders were arrested in 2015 when they prepared to participate in a peace walk organized by MADCA, under the suspicion that they were gathering for a meeting of the outlawed coastal secessionist movement the Mombasa Republican Council. ${ }^{4}$

It is in this historical and political context that the claim of MADCA elders that Giriama Traditionalism is a religion similar and equal to Islam and Christianity becomes relevant. Through this claim, Giriama elders arguably aim to respond to suspicions that Giriama tradition is primitive or immoral, informs subversive political activities, or taps into spiritual forces other than the God of monotheist religions such as Islam and Christianity. The next section explores how such suspicions tacitly influence interactions between MADCA and CICC, even though this cooperation is premised on the idea that Christians, Muslims, and Traditionalists participate in CICC as religious equals.

The Coast Interfaith Council of Clerics (CICC) is a civil society organization that brings clerics from various religious backgrounds together to promote peace and 'interfaith harmony', and to address shared challenges. ${ }^{5}$ The Malindi branch of CICC mainly works with mainline Muslim and Christian groups but also involves representatives of Giriama Traditionalism through cooperation with the Malindi District Cultural Association (MADCA). ${ }^{6}$ During my fieldwork Catholic Relief Services (CRS) and the GHR Foundation funded the Malindi branch of CICC to carry out a 'Dialogue and Action Project' (DAP) to promote 
children's rights, counter child marriages, prevent the sexual abuse of children, and promote peaceful coexistence among participants and the wider community (CRS 2017). ${ }^{7}$ CICC does this by (1) setting up committees of clerics, government officials, and NGO workers in various areas that handle cases of sexual abuse and child marriage, (2) educating children about their rights through peace clubs in schools, and (3) participating in occasional public sensitization events. Finally, because CICC recognizes that poverty often hinders the realization of children's rights, it also supports parents and caregivers in so-called (4) Saving and Lending Communities (SILC groups), in which parents and caretakers contribute savings toward loans to improve their economic conditions and keep girls in school (CRS 2017). ${ }^{8}$

CICC selected schools and areas to be included in the programme based on an assessment of the prevalence of sexual abuse and early marriages. Through these investigations, mainly rural and semi-urban areas around Malindi were identified as focus areas; these are places where the Giriama often form the majority. In my view, this CICC policy echoes more widely shared ideas that the Giriama would be in need of religious education on sexual morality and marriage-related issues, especially since CRS sees the violation of children's rights as not only resulting from poverty and sex tourism, but also from 'negative cultural influences' that it associates specifically with 'Traditionalists' (CRS 2017). This veiled focus on the Giriama was confirmed during an interview with a Catholic staff member of CICC, who argued that Traditionalists in particular lacked knowledge that marrying off an underage child is against the law', and explained that this was the reason why CICc decided to involve representatives of Giriama Traditionalism in the first place, since the programme initially included only Muslim and Christian clerics (CRS 2017). Although it was never explicitly acknowledged during any of the meetings that I attended, CICC's emphasis on the Giriama also came to the fore implicitly during CICC meetings. During various interfaith dialogues that CICC organized, Muslim and Christian leaders discussed disco matanga, which are discos that raise funds for funerals that are organized by Giriama, arguing that they are places where youth are distracted from school-related obligations and engage in immoral sexual activities; girls become pregnant and are then forced to marry despite their young age. During one CICC meeting a Muslim leader explicitly linked disco matanga to Giriama Traditionalism, since he blamed Kaya elders for keeping quiet about the issue and called on them to condemn the practice to prevent further immoral behaviour.

The ambivalent position of the Giriama within CICC is further highlighted in private conversations that I had with Muslim and Christian staff and participants of CICC, who sometimes associated the Giriama with ignorance or 
Giriama ideas and practices with witchcraft. For example, a Muslim leader equated Giriama healing and divinatory practices (uganga) with harmful magic or witchcraft (uchawi). A Christian staff member of CICC told me that she and some of the Christian clerics had feared Giriama elders when they first participated in CICC because she thought their traditional attire indicated that they might be witches (wachawi), but was relieved when she discovered that they also 'pray to one God'. During one conversation, a non-Giriama Christian CICC staff member lamented the ignorance of Mijikenda parents, stating that they take their children to their grandparents and, in her opinion, do not take proper care of them.

Although Muslims and Christians rarely openly express negative attitudes toward Giriama Traditionalism within CICC, some institutional imbalances can be noted within the organization which privilege Islam and Christianity. First, donor funds are primarily provided by Catholic Relief Services, which directly funded the Catholic Diocese of Malindi during two earlier phases of DAP (2010-2016). The diocese subsequently cooperated with CICC to enable interfaith cooperation within the project. During the third phase of DAP (2016-2019), funding was given directly to CICC to stress the interfaith character of the programme. However, the offices of cicc continue to be located at Malindi's Catholic Institute, where many CICC meetings take place that allow Catholic Christians in particular to assume roles as hosts of the programme. The fact that they assume such roles also implies that they are engaged in the catering offered during CICC meetings, and thus have the opportunity to benefit from the funds available for this. The Christian institutional character of the CICC programme is also reflected in the composition of the staff who implement the programme, which during the time I was doing fieldwork consisted of three Christians and one Muslim. The group of clerics involved in the CICC programme was led by one Muslim and one Christian religious leader. Furthermore, an institutional imbalance can also be noted within the educational settings in which CICC promotes children's rights. For example, CICC aids schools in Malindi with the implementation of Programmes of Pastoral Instruction (PPI), during which religious leaders visit schools to provide religious instruction to students. Since the Kenyan educational system does not recognize indigenous African religious traditions, CICC sends only Muslim and Christian clerics to schools in connection with these programmes, forcing students who self-identify as Traditionalists to choose between these two options (Chidongo 2012).

Furthermore, outside of the context of CICC I sometimes interacted with Muslims and Christians in Malindi who explicitly questioned whether Giriama 
Traditionalism should be categorized as dini (religion) since it does not have a consistent theology, places of worship, or holy scriptures. For example, during a dialogue meeting for peace organized by another civil society organization, one Giriama youth who mentioned that 'he did not join a religion yet' (sijaingia dini) was referred to in English as a 'Traditionalist' by a Christian cso worker, signifying that Traditionalism was understood as belonging to a different category than Islamic and Christian religion (dini). In addition, one of my Muslim interlocutors who worked for another cso argued that 'a statue is the lowest thing that one can worship', a statement that could easily be understood as criticism of Giriama engagement with vigango and makoma. In some cases such criticisms were not only forwarded by Swahili Muslims and Christians from 'upcountry' backgrounds, but also by Giriama who self-identify as Christians. ${ }^{9}$

MADCA was founded in 2003 with the aim to revive and promote Giriama culture and religion, through the Mekatilili wa Menza cultural centre, a yearly Mekatilili wa Menza festival, and walks to promote peace (Nyamweru 2013). In addition, MADCA elders frequently reply to requests for mediation in family disputes, or use their knowledge and ritual expertise to solve problems that are understood as relating to the spirit world, such as spirit possessions and witchcraft (utsai). MADCA also holds regular meetings on Sunday mornings (at a time that interferes with church services), in which various matters are discussed among its broader membership (Nyamweru 2013). Despite MADCA's keen interest in promoting Giriama culture and religion among the young, MADCA's membership is dominated by elders aged fifty years and over (Nyamweru 2013). Giriama elders also stated that MADCA's cultural centre is set up to receive and inform researchers who are interested in Giriama culture and tradition, not only to compile and preserve knowledge about Giriama culture and religion but also in the hope that outside recognition and interest will enhance the relevance of and respect for Giriama religion and culture both in Malindi and beyond.

Given the frequent interaction between MADCA and researchers, it is perhaps unsurprising that Giriama elders occasionally use the scholarly term 'African Traditional Religion' (ATR) to refer to Giriama Traditionalism. Comparative religion scholar Geoffrey Parrinder (1954) introduced the term 'ATR' to assert the religiosity of Africans. The term has subsequently been used as part of a broader critical response to earlier denials of the religiosity of Africans in the seventeenth and eighteenth centuries or the characterization of African religion as savage or primitive in the nineteenth century. For example, the Kenyan theologian John Mbiti (1969) uses the term 'ATR' (in the singular) to argue that indigenous African religiosity offers a systematic philosophy 
that is commensurate with 'world religions' such as Christianity and Islam (Grillo, Van Klinken and Ndzovu 2019). While Mbiti's intervention is important because of its aim to foster respect for the ideas, beliefs, and thoughts of Africans, it generally overplayed commonalities between different expressions of indigenous religiosity across the African continent and overemphasized features that are consistent with Christian doctrine, such as belief in a Supreme Being (Grillo, Van Klinken and Ndzovu 2019). ${ }^{10}$ Later in the twentieth century the term 'ATR' was adopted by various neotraditional movements that similarly wish to overcome marginalization and stigmatization by reforming and remodeling indigenous African religiosity as a world religion, often borrowing extensively from Christian forms and ideas (De Witte 2010, 2015). The use of the term ATR by Giriama elders thus not only reveals their awareness that the character and status of indigenous African religiosity have often been highly contested, but also hints at their desire that Giriama Traditionalism is to be recognized as a religion that is accorded the same public recognition as Christianity and Islam.

During my fieldwork I regularly visited MADCA's cultural centre to learn from elders, and to play music with a group of Giriama elders and musicians from Nairobi. During my extensive interactions at MADCA I noticed that particular topics were repeatedly the focus of conversation. The first, which Giriama elders often discussed, was how Giriama youth frequently accuse elders of practicing witchcraft, and sometimes even kill them following such an accusation. MADCA elders explained that these accusations are often motivated by a desire to acquire access to land and wealth, which they inherit after chasing away or killing elderly relatives.

The cooperation between MADCA and CICC was another common topic of discussion at MADCA. Elders complained that they were frequently excluded from CICC activities for which participants receive lucrative payment, not allowed to assume leadership positions, and were only included in CICC because donors demanded inclusiveness. They also grumbled that Muslim and Christian clerics rarely responded to invitations to attend MADCA's cultural activities, and assumed that they rejected the invitations because they were frightened of being publicly associated with Traditionalism. MADCA elders also discussed CICC's request that Muslims, Christians, and Traditionalists should provide a theological foundation for the protection of children's rights by providing scriptural references to holy books. This request produced complications since Giriama Traditionalists do not have a holy book such as the Quran or the Bible from which they could quote. ${ }^{11}$ Finally, a few Giriama elders also complained that they were not allowed to eat from a lunch buffet at a luxurious resort called Scorpio Villas, which was provided as part of a CICC 
meeting. Although the decision to refuse access to the buffet was made by hotel staff, who considered the traditional attire of Giriama elders to be revealing and unhygienic, Giriama elders resented the fact that their Christian and Muslim colleagues made no effort to challenge this decision.

In my extensive conversations with Giriama elders, they also frequently responded to criticism they anticipated from Muslims and Christians about Giriama ritual practice. As seen in the opening vignette of this article, one Giriama elder defended Giriama engagement with makoma and vigango by comparing the role of ancestors to the intermediate role of saints in Catholic prayer. This comparison resonates with a Giriama prayer in which ancestral spirits are referred to as 'Sheikhs and Sherifs' and a similar comparison is made between Giriama ancestors and Muslim religious figures (Tinga 1998). Likewise, the elder also compared makoma and vigango to the symbolic role of the cross in Christian prayer, and argued that makoma and vigango demonstrate that African Traditional Religion shares with other religions a conception of life after death. In defence of Giriama traditional dress, the elder compared the colours of Giriama traditional attire to the Christian Trinity, with white standing for the purity of Jesus, blue for the divinity of the Father, and red for the bravery and the fire of the Holy Spirit.

These observations demonstrate how MADCA elders often point to similarities between Giriama practices and ideas, and those of their Muslim and Christian neighbours. They arguably do so to strengthen the idea that Giriama Traditionalism is a religion similar and equal to Islam and Christianity. This claim is relevant because Christians and Muslims within CICC sometimes criticize Giriama culture for condoning or even supporting sexual immorality, see Giriama as ignorant and in need of religious guidance, or associate Giriama practices or dress with witchcraft. Such criticism reveals that CICC's interfaith cooperation implicitly takes Islamic and Christian conceptions of religion and morality as a starting point, despite the organization's premise that Christians, Muslims, and Traditionalists are accepted as religious equals. In what follows I highlight four strategies that allow MADCA elders to 'speak back' against Muslim and Christian criticism but simultaneously entail that they appropriate terms, norms, and ideals that are not necessarily of their own making (Comaroff and Comaroff 1992). These strategies also require that MADCA elders selectively mobilize, objectify, and mediate traditional Giriama ideas and practices in ways that align with Christian and Islamic conceptions of religion and morality (Meyer 2015). These strategies are (1) mobilizing Giriama Traditionalism to promote peace, (2) stressing the morality of Giriama Traditionalism, (3) emphasizing that there is only one God, and (4) appealing for religious freedom through a civil court case. 
Although Muslims and Christians sometimes criticize Giriama Traditionalism, such criticism was only rarely openly addressed during the CICC activities in which I participated. This observation can be explained in relation to a wider inclination that I observed in Malindi in which state actors, religious leaders, and csos strive to present themselves as inclusive and sensitive to the needs of various ethnic and religious groups. Similarly, CICC's public legitimacy and access to donor funds also rely on its capacity to present itself as an inclusive organization that promotes peace and interfaith harmony by according equal respect to various religious traditions. In this context directly or publicly associating early marriages and sexual abuse with Giriama Traditionalism would overtly stigmatize the Giriama and damage CICC's reputation as an organization that works toward 'a divinely, peaceful, harmonious and inclusive society of Kenya..12

The requirement to publicly support unity and inclusivity also makes it difficult for Giriama elders to directly address the feelings of exclusion and stigmatization that they experience within CICC. In a context where religious leaders are commonly expected to preach peace and inclusivity, elders are aware that the public airing of Giriama grievances could easily confirm stereotypes that embracing one's 'culture breeds tribalism' (Nyamweru 2013, 255). This in turn could challenge MADCA's claim that Giriama Traditionalism, like Islam and Christianity, is a legitimate contributor to morality, peace, and national unity. Furthermore, unlike Muslims and Christians, MADCA cannot rely on international links to members of their religious group to mobilize funds for development and peace projects. Rather, Giriama elders often depend on being included in organizations like CICC to fulfill public roles that are similar to those of Muslim and Christian clerics, so openly criticizing their position in CICC would be biting the hand that feeds them. Nevertheless, MADCA regularly uses its limited resources, raised by member contributions and well-wishers, for activities that resemble the efforts of Muslim and Christian clerics to promote peace, development, and national unity. For example, MADCA regularly organizes peace walks to promote national unity or to campaign against gender-based violence. Furthermore, during the Mekatilili wa Menza cultural festival in 2017, MADCA elders organized a procession in which they carried a statue of Mekatilili wa Menza through Malindi town. During the event MADCA elders not only promoted Mekatilili wa Menza as a national heroine for resisting British colonization, but also used the occasion to preach peace and national unity in the process (Carrier and Nyamweru 2016). 
MADCA elders also frequently stressed that Giriama Traditionalism supports morality. For example, during a CICC meeting Giriama elders responded to calls from a Muslim leader to condemn disco matanga by arguing that the custom is 'not part of their tradition, but a new tradition'. Although a Christian pastor also suggested that disco matanga are related to Traditionalism, both CICC staff members and several other participants accepted MADCA's line of reasoning, and went on to argue that organizing disco matanga is a 'new tradition' (mila mpya) or the result of youth who 'misinterpret religion' (wanadanganya dini) to create a 'dot-com religion'. By associating immorality with 'new youth traditions' rather than Giriama tradition, Giriama elders aim to uphold their claim that Giriama Traditionalism is a legitimate source of morality, and does not support the alleged sexual immorality that takes place at disco matanga.

In several ways, disco matanga do indeed deviate from earlier Giriama funeral practices because they include several elements that I did not find among earlier anthropological accounts of Giriama funeral rites. The use of sound systems to attract guests and financial contributors in the week leading up to a funeral is new. This is where the name disco matanga (literally 'funeral disco') comes from. These sound systems are used for speeches by family members and honourable guests and to play popular music. According to some interlocutors, this often happens at the expense of traditional singing, drumming, and dancing (Udvardy 2013). ${ }^{13}$ Some of my interlocutors said that the custom of collecting funds for funerals was initiated by Luo people, who settled in Malindi and organized similar events to collect funds to pay for the bodies of deceased relatives to be transported home to Western Kenya for burial. The Giriama copied this practice to cover the huge costs involved in organizing funerals.

In several aspects, however, disco matanga are a continuation of earlier funeral practices among the Giriama. Various anthropologists have described how Giriama funerals are events of major social and political significance and include six or seven days of ceremonial rites, feasting, dancing, and the copious consumption of palm wine and sacrificial meat (Udvardy 2013; McIntosh 2005b, 2009; Parkin 1972, 1991). According to David Parkin (1972, 1991), Giriama funerals function not only to mourn the deceased but also as important sites in which to exchange wealth, form social and political ties, display generosity and hospitability, and express sociability and rivalry between generations and neighbourhoods, and they can draw crowds of hundreds of people. Although 
disco matanga do not always include traditional rituals, singing, and dancing, they continue to be events of major social and political importance. Disco matanga commonly draw large crowds, and are attended by politicians who contribute food, drinks, or money to raise political support and legitimacy. Disco matanga are also sites of economic exchange. Several traders in palm wine, sodas, bottled beer, and foods make a living from selling their goods at these events, while food, drinks, and alcohol may be exchanged or provided by guests and other contributors. Scholars have described how Giriama funerals commonly provide occasions for young men and women to meet one another, engage in dancing, and initiate or continue love affairs, while adult men and women may sing sexually charged songs. These practices significantly deviate from the usual Giriama standards, especially those relating to women's sexual modesty, although sexual intercourse itself is forbidden during funeral rituals (Udvardy 2013; Parkin 1972, 1991; McIntosh 2005b; Ngala 1949). Similarly, disco matanga also provide occasions for youth to meet and dance with one another. Several young interlocutors confirmed that disco matanga have become increasingly popular as meeting places because drinks and entrance fees at Malindi's tourist-oriented bars and discotheques are too expensive for many young Giriama.

Finally, the rejection of aspects of Giriama funerals is not a new phenomenon. Anthropologist Janet McIntosh notes that Swahili Muslims commonly frown on 'the lengthy funerals involving dance and drink' of the Giriama (2009, 204). Furthermore, Parkin $(1991,195)$ states that there has been a long history in which colonial and postcolonial governments have 'tried to control the length, timing, and amount of money and animals dispensed at funerals, as well as the ritually and socially important drinking of palm wine' because they considered these practices a waste of energy, time, and resources. The rejection of disco matanga as a source of sexual immorality by Muslim and Christian leaders in CICC thus builds on a longer colonial and postcolonial history in which dancing, lavish feasting, and alcohol consumption at Giriama funerals is rejected as wasteful and immoral. By arguing that immoral aspects of disco matanga result from 'youth innovations' and do not resemble 'traditional' Giriama funerals, however, MADCA elders aim to uphold their claim that Giriama Traditionalism is morally equal to Islam and Christianity.

Furthermore, in response to CICC's request that a theological foundation should be provided to justify the protection of children's rights by providing scriptural references to holy books, MADCA organized a meeting at which a few Giriama elders discussed the relation between Giriama Traditionalism and children's rights. During the meeting one Giriama elder stressed that 'religion is about morality', which in the case of the Giriama is not mediated by 
a holy book but part of the 'way of life' of 'African religion'. The elders also argued that although the Giriama did not keep a record of a child's age, none of the girls were married off before they were physically mature. Another elder subsequently explained that it has previously been uncommon for women to give birth at home; if a woman did so, it indicated that she had been sexually active before marriage because marriage usually involves a woman moving into her husband's homestead. Finally, this elder argued that sexual abuse and immorality is not limited to the Giriama but also takes place in mosques and churches. Through such arguments Giriama elders challenged the idea that early marriages and sexual abuse result from negative cultural influences. They rather see sexual behaviour that is deemed immoral as stemming from children 'being taken away from their cultural roots' and the supervision of elders because children's time is increasingly taken up by the modern school system and visits to mosques, madrassas, and churches. ${ }^{14}$ Giriama elders proposed that the solution would be to 'instill morality' into youth at MADCA's cultural centre during school holidays.

In relation to their claims that Giriama Traditionalism is a religion equal to Islam and Christianity, MADCA elders also frequently emphasize that Giriama Traditionalism worships 'one God'; they do this to avoid confirming common suspicions that Giriama ritual practice is idolatrous or that it engages other spiritual forces, such as witchcraft. Various scholars have written that Giriama ritual practice engages a supreme being called Mulungu in Mijikenda languages. However, Mulungu is also described as a distant god and 'not a very vivid agent' (McIntosh 2009, 196), who mainly bears environmental responsibilities such as for rainfall and the growth of crops (see also: Udvardy 2013; Parkin 1991). Generally, the Giriama only directly appealed to Mulungu during ritual practice in sacred Kaya forests, during calamities and periods of extended drought. Indeed, early missionaries complained that Mijikenda had only very vague conceptions of Mulungu, making it difficult to interest Mijikenda in the Christian God as an alternative (Sperling 1988). Many Giriama continue to believe that their daily lives are influenced by numerous other spiritual forces such as spirits (mapepo or majini), the spirits of ancestors (koma), or witchcraft (utsai) (Brantley 1979; McIntosh 20o9; Parkin 1991). Consequently, many Giriama, alongside others from various ethnic and religious backgrounds, use the services of waganga to diagnose and heal illnesses and alleviate the misfortunes that various spiritual forces and entities may cause. 
Researchers have detailed how Giriama used to erect vigango and makoma in extended-family homesteads, where they were thought to incarnate the spirits of deceased ancestors, but today this is uncommon among Giriama living in and around Malindi. David Parkin $(1981,6)$ describes how, after an elaborate installment ritual, 'the spirit and its wooden memorial are closely identified, and become in effect the same thing' and are referred to with the same word, koma. Since vigango and makoma materially render ancestors present, they are given frequent food and palm-wine libations accompanied by prayers (Sperling 1988). Ancestor spirits are also thought to have the power to disrupt the fortune of homestead dwellers when neglected or disturbed (Brantley 1979; Spear 1978; Parkin 1991; McIntosh 2009; Udvardy 2013). Although ancestors are often invoked simultaneously with God through the phrase Koma tsi, Mulungu $d z u l u$ ('Ancestors below, God above'), they are also understood to operate independently from God and to demand separate ritual attention (Tinga 1998).

However, in the previously referred to explanation of vigango and makoma of one Giriama elder, this elder emphasizes how the Giriama do not adore vigango and makoma themselves and that these wooden posts merely symbolize deceased ancestors. Furthermore, by comparing vigango and makoma to Catholic saints, the elder highlights how ancestors perform an intermediary function between the Giriama and God rather than being an autonomous force that ancestors are also commonly thought to possess (McIntosh 2009). Through such reasoning, this Giriama elder arguably responds in two connected ways to Muslim and Christian claims that the Giriama are idolatrous because they worship statues. First, rather than conceptualizing vigango and makoma and the ancestors they represent as essentially the same thing, he makes a distinction between the icons (wooden posts) and their referents (ancestor spirits) by emphasizing that the wooden posts merely symbolize ancestors. Gottfried Boehm (1997) conceptualizes the maintenance of a distinction between an icon or image and what it represents as the upholding of 'iconic difference'. According to Birgit Meyer (2019), the recognition of iconic difference has often been seen as differentiating 'civilized' forms of religiosity, such as Christianity, from the so-called idolatry, superstition, and backwardness of Africans during missionary and colonial encounters. The creation of iconic difference is thus relevant for this elder, because it counters claims that the Giriama are idolatrous because they worship statues and by doing so fail to understand icons as mere representations. Second, by stressing that ancestors perform an intermediary function between the Giriama and God, the Giriama elder underscores that God is the ultimate object of veneration in Giriama ritual practice, not ancestors. In this way, he aligns Giriama ritual practice with Christianity and Islam, which both see God as the one and only being that deserves to be worshipped. 
Interestingly, while MADCA elders often emphasize the relationship between Giriama Traditionalism and a Supreme Being, at other times MADCA downplays religious aspects of practices that engage spiritual forces other than the one God. During colonial times missionaries and British officials recognized that in the eyes of the Giriama dancing, drumming, and singing could facilitate engagement with invisible spiritual forces. Consequently, they considered indigenous African dancing and drumming (ngoma) to be 'wicked' and 'heathen practices', and encouraged the development of 'civilized' musical alternatives (Ranger 1975). Similarly, during postcolonial times administrative agents often restricted ritualized dancing because they feared that large dancing events would provide opportunities for political activity or the concentration of power in ritual practitioners who could challenge state authority (Ciekawy 1998). Such Christian and state condemnation of indigenous dancing and drumming resonates in the present day. For example, one Giriama interlocutor explained that it is considered unacceptable to take traditional percussive instruments to churches since Christians see them as 'devilish'.

For many Giriama traditional ways of singing, drumming, and dancing continue to carry religious connotations (Udvardy 2013). Within the context of the Mekatilili wa Menza festival, however, MADCA advertises them as culture (utamaduni) or arts (usanii), rather than religious activities. ${ }^{15}$ According to one MADCA elder, this is because the festival is primarily meant to be a showcase of Giriama culture in which no actual treatment or engagement with the spiritual realm takes place. Since MADCA often invites Muslims and Christians to cultural activities (even though they rarely attend), presenting dances as cultural activities allows MADCA to enhance the public presence of Giriama Traditionalism, while downplaying how such activities are also conceived as mediating engagement with the spiritual world, which many Muslims and Christians would consider offensive or idolatrous. One MADCA elder also explained that although Giriama healing practices often involve Islamic elements such as the Qur'an, MADCA excludes Islamic elements during cultural activities because Muslims could misunderstand this as ridiculing their religion. Besides downplaying how Giriama ideas and practices engage a variety of spiritual forces, MADCA thus also tends to present Giriama tradition as self-contained and separate from Christianity and Islam when it publicly showcases Giriama culture, ignoring patterns of borrowing and mutual influence that also characterize modes of religious coexistence in coastal Kenya (McIntosh 2009).

MADCA elders use a similar strategy when they explain witchcraft accusations that Giriama youth sometimes make against elderly relatives. They often emphasize how these accusations are motivated by the desires of youth to inherit the material wealth of elderly relatives and that the young are 
suffering from 'a loss of morals' or are 'no Muslim, no Christian, but also no Traditionalist'. Through such reasoning, MADCA elders suggest that anxieties about witchcraft among youth are motivated by selfish interests and caused by a lack of respect for Giriama Traditionalism rather than being indicative of a persistent influence of Giriama religious cosmology and ritual practice on youth, which commonly recognizes the dangers of witchcraft (utsai) (Ciekawy 1998; Brantley 1979). ${ }^{16}$

In other cases MADCA elders emphasize that the worship of one God is central to Giriama Traditionalism. For example, I never heard MADCA elders at CICC meetings refer to spiritual forces or entities other than God, even when they were given the opportunity to open or close CICC meetings with prayers. In this way, MADCA's elders have arguably been able to reassure the CICC staff member who suspected Giriama elders of being witches that they also pray to one God. Finally, during the previously mentioned conversation about children's rights at MADCA, one MADCA elder used Christian terminology to argue that the fact that the Giriama do not have holy scriptures does not mean that they rely on spiritual forces or entities other than God: 'The issue is they worship God, they don't worship the Devil'.

In response to their experience of being denied access to a lunch buffet at Scorpio Villas, two MADCA elders filed a plaint in 2014 to begin a civil court case against Scorpio Villas at the Malindi High Court. ${ }^{17}$ In the plaint MADCA elders claimed that not being allowed to participate in the buffet not only caused them 'injured feelings' and 'defamation of character', but also a 'breach of constitutional rights', namely being protected from discrimination on the grounds of faith, culture, and age (Kenyan Constitution of 2010, Art. 27.4). In relation to the alleged harms that they had suffered, MADCA elders demanded an apology from the hotel, unspecified 'general damages', as well as a court injunction restraining further discriminatory action by the hotel.

Interestingly, in the plaint MADCA elders purposely left open the possibility of the court categorizing the wearing of traditional attire as a religious or a cultural practice, although they emphasized that they wear traditional attire because it represents their 'indigenous faith' within CICc. When I discussed the court case with one of the MADCA members, this elder explained that MADCA elders decided to do this to test whether the court would categorize Giriama Traditionalism as a religion or a culture, and whether the court would 
be willing to provide protection on either of these two grounds. He summarized the idea behind the civil case as follows:

People are confused. They think religion is a building, clergy, scriptures, an organized group, a fellowship. But religion is a relation with God.... There is no religion without prayer.... If you look at Islam, it is a way of life. Even Christianity. And this life spiritually leads you to God. And African Traditional Religion is a way of life also.... So there must be a moral code, ethics, that will lead to God.... All these things are present in African Traditional Religion.

Conversation with MADCA elder, 15 August 2017

From this quotation it is clear what this Giriama elder considers to be the central aspects of religion, namely morality, ethics, and a relation with God through prayer. He argues that since Giriama Traditionalism fits these requirements it should be accorded the same state protection and public recognition as Islam and Christianity. Although the plaint was filed in 2014, to date the court case is still pending, leaving the result of the case unclear. Nevertheless, the plaint provides insights into the ways in which MADCA elders seek constitutional protection for Giriama Traditionalism against discrimination on cultural and religious grounds.

\section{Conclusion}

This article explores how Giriama elders in MADCA aim to strengthen the idea that Giriama Traditionalism is a religion similar and equal to Christianity and Islam. This claim is relevant because despite being premised on the idea that Christians, Muslims, and Traditionalists are religious equals, the interfaith cooperation within CICC continues to associate Giriama Traditionalism with the 'negative cultural influences' it intends to counter. Furthermore, Giriama elders in MADCA also need to navigate suspicions that they hold 'primitive superstitions', take part in subversive political activities, or engage spiritual forces other than the monotheist God of Islam and Christianity. Such suspicions find their roots in a longer Kenyan history in which the demarcation of 'good' religiosity from witchcraft and 'morally repugnant' African practices formed a central aspect of colonial and postcolonial statecraft.

Giriama elders in MADCA have developed various strategies to navigate and challenge Muslim and Christian criticism. These strategies are (1) promoting 
peace, (2) stressing morality, (3) emphasizing a Supreme Being, and (4) appealing for religious freedom through a civil court case. Through these strategies Giriama elders in MADCA arguably aim to represent Giriama Traditionalism as moral, monotheist, and peaceful, and hence similar and equal to Islam and Christianity. While these strategies allow MADCA elders to speak back against Muslim and Christian criticism, this is done on terms not necessarily of their own making. These strategies imply that MADCA elders represent Giriama Traditionalism in ways that align with Islamic and Christian conceptions of religion and morality, which implicitly inform interfaith cooperation within CICC. Since MADCA's strategies are entangled with earlier (post)colonial debates and contestations, the interfaith dialogues within CICC can be understood as part of a 'long conversation' in which the character and status of indigenous African religiosity has often been questioned (Comaroff and Comaroff 1992). Because Christianity has been institutionally dominant in this conversation since British colonial times, it is perhaps unsurprising that Christian norms, ideas, and practices inform the strategies through which MADCA elders hope to gain recognition as representatives of a religion, similar to adherents of African Traditional Religions elsewhere (De Witte 2010, 2015).

Although inclusion in CICC gives MADCA elders an opportunity to publicly represent their traditional religion, Islamic and Christian conceptions of (good) religion and morality strongly inform how Giriama Traditionalism is mobilized and expressed. To be included in civil society cooperation and taken seriously as representatives of a religion, Giriama elders need to commit to ideals of peace, morality, and national unity. This severely limits possibilities of publicly challenging the economic and political marginalization about which many Giriama privately complain, or to address the long history in which Giriama beliefs and practices have been condemned or looked down on as backward. This limitation is further enhanced by MADCA's dependence on Muslims and Christians for their inclusion in CICC. These dynamics may limit the potential of MADCA and CICC to work toward the 'peaceful, harmonious and inclusive society of Kenya' they envision.

\section{Acknowledgements}

My gratitude goes out to my interlocutors within MADCA and CICC, who are anonymized in this article. I am thankful toward Birgit Meyer, Hassan Mwakimako, Benjamin Kirby, Hanna Nieber and Benedikt Pontzen who read earlier versions of this article and provided valuable comments and suggestions. I also appreciate the comments I received on this paper during the $\mathrm{PhD}$ 
course 'Magic, Spirits and Power: Transgressing the Religious / Secular Divide' at the University of Copenhagen in 2018, and from the two anonymous reviewers of the Journal of Religion in Africa.

\section{References}

Ambani, J.O., and O.L. Ahaya. 2015. 'The Wretched African Traditionalists in Kenya: The Challenges and Prospects of Customary Law in the New Constitutional Era'. Strathmore Law Journal 1.1, 52-69.

Boehm, Gottfried. 1997. 'Die Lehre des Bilderverbots'. In B. Recki and L. Wiesing (eds.), Bild und Reexion, Paradigmen und Perspektiven gegenwärtiger Ästhetik. Munich: Fink Verlag, 294-306.

Brantley, Cynthia. 1973. The Giriama Rising, 1914: Focus for Political Development in the Kenya Hinterland, 1850-1963. PhD diss., University of California.

Brantley, Cynthia. 1979. 'An Historical Perspective of the Giriama and Witchcraft Control.'Journal of the International African Institute 49.2, 112-133.

Brenner, Louis. 1989. "Religious” Discourses in and about Africa'. In Karin Barber and P.F. de Moraes Farias (eds.), Discourse and its Disguises. The Interpretation of African Oral Texts. Birmingham: Birmingham University Studies Series No. 1, Centre of West African Studies.

Carrier, Neil, and Celia Nyamweru. 2016. 'Reinventing Africa's National Heroes: The Case of Mekatilili, A Kenyan Popular Heroine'. African Affairs 115.461, 599-620.

Chidester, David. 2014. Empire of Religion: Imperialism and Comparative Religion. Chicago, IL: University of Chicago Press.

Chidongo, T.M. 2012. Exploring Dialogue; Reflections on Christianity's Mission and African Indigenous Religion. Germany: Lambert Publishers.

CICC [Coast Interfaith Council of Clerics]. 2019. African Traditional Religion's Involvement in Peace Building.

Ciekawy, Diane. 1998. 'Witchcraft in Statecraft: Five Technologies of Power in Colonial and Postcolonial Coastal Kenya'. African Studies Review 41.3, 119-141.

Ciekawy, Diane. 2009. 'Demonic Tradition: Representation of Oathing in Newspaper Coverage of the 1997 Crisis in Coastal Kenya'. In Kimani Njogu and John Middleton (eds.), Media and Identity in Africa. Edinburgh: Edinburgh University Press Ltd, 287-307.

Cooper, Frederick. 1980. From Slaves to Squatters: Plantation Labor and Agriculture in Zanzibar and Coastal Kenya, 1890-1925. New Haven, CT: Yale University Press.

Comaroff, John L., and Jean Comaroff. 1992. Ethnography and the Historical Imagination. Boulder, CO: Westview Press. 
Cotran, Eugene. 1983. 'The Development and Reform of Law in Kenya'. Journal of African Law 27.1, 42-61.

CRS (Catholic Relief Services). 2017. Interreligious Action for Peace. Studies in MuslimChristian Cooperation, Tom Barnat, Nell Bolton, Myla Leguro, and Atalia Omer (eds.). Baltimore, MD: Catholic Relief Services.

Cruise O'Brien, Donal B. 1995. 'Coping with the Christians: The Muslim Predicament in Kenya'. In Holger Bent Hansen and Michael Twaddle (eds.), Religion \& Politics in East-Africa. Athens: Ohio University Press, 269-304.

de Witte, Marleen. 2010. 'Transnational Tradition: The Global Dynamics of "African Traditional Religion"'. In Afe Adogame and James V. Spickard (eds.), Religion Crossing Boundaries. Transnational Religious and Social Dynamics in Africa and the New African Diaspora. Leiden: Koninklijke Brill NV, 253-275.

de Witte, Marleen. 2015. 'Media Afrikania. Styles and Strategies of Representing "Afrikan Traditional Religion" in Ghana'. In Rosalind I.J. Hackett and Benjamin F. Soares (eds.), New Media and Religious Transformations in Africa. Bloomington: Indiana University Press.

Gearhardt, Rebecca, and Linda Giles. 2013. 'Introduction'. In Rebecca Gearhardt and Linda Giles (eds.), Contesting Identities, the Mijikenda and their Neighbors in Kenyan Coastal Society. Trenton, NJ: Africa World Press, xiii-xxxviii.

Grillo, Lauren S., Adriaan van Klinken, and Hassan J. Ndzovu. 2019. Religions in Contemporary Africa. An Introduction. London: Routledge.

Hackett, Rosalind I.J. 2011. 'Regulating Religious Freedom in Africa'. Emory International Law Review 25, 853-879.

Hackett, Rosalind I. 2015. 'Traditional, African, Religious, Freedom?' In Winnifred Fallers Sullivan, Elizabeth Shakman Hurd, and Saba Mahmood (eds.), Politics of Religious Freedom. Chicago, IL: Chicago University Press.

Harrington, John. 2018. 'Governing Traditional Medicine in Kenya: Problematization and the Role of the Constitution.' African Studies 77.2, 223-39. DoI: 10.1080/ ooo20184.2018.1452856.

Janson, Marloes, and Birgit Meyer. 2016. "Introduction: Towards a Framework for the Study of Christian-Muslim Encounters in Africa." Africa 86.4, 615-619.

Kenyatta, Jomo. 1938. Facing Mount Kenya. The Traditional Life of the Kikuyu. London: Heinemann.

KLRC [Kenya Law Reform Commission]. 2014. Justification for Review of Witchcraft Act Cap 67. Published December 15. Last accessed: September 15, 2021. http://www.klrc .go.ke/index.php/klrc-blog/518-justification-for-review-of-witchcraft-act-cap-67.

Kresse, Kai. 2009. 'Muslim Politics in Postcolonial Kenya: Negotiating Knowledge on the Double-Periphery'. Journal of the Royal Anthropological Institute. 15.1, 76-94.

Kresse, Kai. 2019. Past Present Continuous: Post-Colonial Experience and Swahili Muslim Publics in Coastal Kenya. Bloomington: Indiana University Press. 
Leatt, A.M.J. 2011. The State of Secularism. Constituting Religion and Tradition towards a Post-Apartheid South Africa. Ph.D. dissertation, the University of the Witwatersrand.

Luongo, Katherine. 2011. Witchcraft and Colonial Rule in Kenya, 1900-1955. New York: Cambridge University Press.

Mazrui, Alamin M. 2016. Cultural Politics of Translation. East Africa in a Global Context. New York: Routledge.

McIntosh, Janet. 2004. 'Reluctant Muslims: Embodied Hegemony and Moral Resistance in a Giriama Spirit Possession Complex'. The Journal of the Royal Anthropological Institute 10.2, 91-112.

McIntosh, Janet. 2005a. 'Language Essentialism and Social Hierarchies among Giriama and Swahili'. Journal of Pragmatics 37, 1919-1944.

McIntosh, Janet. 2005b. 'Liminal Meanings: Sexually Charged Giriama Funerary Ritual and Unsettled Participant Frameworks'. Language and Communication 25, 39-6o.

McIntosh, Janet. 2009. The Edge of Islam: Personhood, and Ethnoreligious Boundaries on the Kenya Coast. Durham, NC: Duke University Press.

Meyer, Birgit. 1999. Translating the Devil. Religion and Modernity among the Ewe in Ghana. Edinburgh: University Press.

Meyer, Birgit. 2015. Sensational Movies: Video, Vision, and Christianity in Ghana. Oakland: University of California Press.

Meyer, Birgit. 2019. 'Idolatry Beyond the Second Commandment: Conflicting Figurations and Sensations of the Unseen'. In Birgit Meyer and Terje Stordalen (eds.), Figurations and Sensations of the Unseen in Judaism, Christianity and Islam, Contested Desires. London: Bloomsbury Academic.

Middleton, John. 1992. The World of the Swahili. An African Mercantile Civilization. New Haven, CT: Yale University Press.

Mitsanze, John Baya, and Linda Giles. 2013. 'The Kaya Legacy. The Role of the Mijikenda Makaya and Kaya Elders in Postcolonial Kenya'. In Rebecca Gearhardt and Linda Giles (eds.), Contesting Identities, the Mijikenda and their Neighbors in Kenyan Coastal Society. Trenton, NJ: Africa World Press.

Mkangi, Katama. 1995. 'The Perception of Islam by the Mijikenda of Kenya Coast'. In M. Bakari and S.S. Yahya (eds.), Islam in Kenya. Mombasa: Muslim Educational and Welfare Association, 109-115.

Mutua, Makau. 1999. 'Returning to my Roots, African "Religions" and the State'. In Abdullahi Ahmed An-Na'im (ed.), Proselytization and Communal Self-Determination in Africa. Maryknoll, NY: Orbis Books.

Ngala, R.G. 1949. Nchi na Desturi za Wagiriama. Nairobi: The Eagle Press.

Nyamweru, Celia. 2013. 'Identity Politics and Culture in Coastal Kenya: The Role of the Malindi District Cultural Association'. In Rebecca Gearhardt and Linda Giles (eds.), Contesting Identities, the Mijikenda and their Neighbors in Kenyan Coastal Society. Trenton, NJ: Africa World Press. 
Parkin, David. 1970. 'Politics of Ritual Syncretism: Islam among the Non-Muslim Giriama of Kenya'. Journal of the International African Institute 40.3, 217-233.

Parkin, David. 1972. Palms, Wine, and Witnesses. London: Intertext Books.

Parkin, David. 1981. 'Speaking of Art: A Giriama Impression'. First Annual Alan P. Merriam Memorial Lecture, 21 October. Indiana University, Bloomington, Indiana.

Parkin, David. 1989. 'Swahili Mijikenda: Facing Both Ways in Kenya'. Journal of the International African Institute 59.2, 161-175.

Parkin, David. 1991. Sacred Void: Spatial Images of Work and Ritual among the Giriama of Kenya. Cambridge: Cambridge University Press.

Peterson, Derek R. 2002. 'Gambling with God: Rethinking Religion in Central Kenya'. In Derek R. Peterson and Darren Walhof (eds.), The Invention of Religion: Rethinking Belief in Politics and History. New Brunswick, NJ: Rutgers University Press, 37-58.

Ranger, Terence. 1975. Dance and Society in Eastern Africa, 1890-1970: The Beni Ngoma. London: Heinemann.

Smith, James Howard. 2008. Bewitching Development: Witchcraft and the Reinvention of Development in Neoliberal Kenya. Chicago, IL: University of Chicago Press.

Spear, Thomas T. 1978. The Kaya Complex: A History of the Mijikenda Peoples of the Kenya Coast to 1900. Nairobi: Kenya Literature Bureau.

Sperling, David Colton. 1988. The Growth of Islam among the Mijikenda of the Kenya Coast, 1826-1933. Ph.D. diss., School of Oriental and African Studies, University of London.

Tinga, Kaingu Kalume. 1998. 'Cultural Practice of the Midzichenda at Cross Roads: Divination, Healing, Witchcraft and the Statutory Law'. Afrikanistische Arbeitspapiere 55, 173-184.

Udvardy, Monica. 2013. 'Loss of Purity? Kenyan Ethnic Politics and the Reality of Giriama Fantasies of Coastal Culture'. In Rebecca Gearhardt and Linda Giles (eds.), Contesting Identities, the Mijikenda and their Neighbors in Kenyan Coastal Society. Trenton, NJ: Africa World Press.

Willis, Justin. 1993. Mombasa, the Swahili, and the Making of the Mijikenda. Oxford: Clarendon Press.

Wipper, Audrey. 1977. Rural Rebels. A Study of Two Protest Movements in Kenya. Nairobi: Oxford University Press.

\section{Notes}

1 The Gohu society is a semi-secret organization with branches in various localities. It is a social group for senior elders for fraternal enjoyment (Udvardy 2013, 78).

2 In English, dini ya jadi is often referred to as 'traditionalism' by its adherents and by Muslims and Christians in Malindi. To differentiate the traditionalism of the Giriama from other forms of indigenous African religiosity, I use the term 'Giriama Traditionalism' here. While 
the Kiswahili term 'dini' (religion) was originally used primarily by Swahili Muslims to refer to Islam, the term was appropriated by Christian missionaries to refer to various religions, including Christianity, during British colonialism. In relation to this complex history in which the semantic resonances of the English term 'religion' and the Kiswahili term 'dini' have come to overlap, MADCA's use of the Swahili loanword 'dini' signifies how Giriama elders wish to claim for Giriama Traditionalism the status and recognition as a religion that is equal to both Islam and Christianity, even though the Giriama language itself does not have a direct equivalent for the term 'religion'.

Anthropologist Diane Ciekawy (2009) argues that such fears find their roots in colonial times, when British officials associated both the Mau Mau revolt among the Kikuyu in the 195 os and the Giriama uprising of 1914 with witchcraft and 'demonic oathing' practices to delegitimize these movements. https://kilifinews.blogspot.com/2015/o7/5o-peace-walkers-arrested-in-malindi.html. http://cicckenya.org/index.php/about-cicc/core-values-beliefs.

6 In Malindi these groups are the Supreme Council of Kenya Muslims (supkem), the Council of Imams and Preachers of Kenya (CIPK), representatives of the Catholic Church and mainline Protestant denominations, and a few pastors of independent Pentecostal or Evangelical churches (CRS 2017, 63).

$7 \quad$ During many of the CICC meetings that I attended child marriages were often referred to as 'early marriages' (ndoa za mapema).

8 http://www.ghrfoundation.org/news/dialogue-and-action-project-representatives-meet -with-president-kenyatta; http://www.ghrfoundation.org/news/category/kenya; https:// sites.nd.edu/contendingmodernities/2016/10/06/united-for-girls-rights-a-reflection/.

9 During fieldwork I met several Giriama Christians who considered Christianity to be superior to Giriama Traditionalism and who associated Giriama ritual practice with witchcraft (uchawi). However, I also met Giriama Christians who took mild stances toward Giriama Traditionalism. For example, some Giriama Christians categorized Giriama Traditionalism not as a dini (religion) but as mila (tradition) or desturi (custom). Such a categorization allowed these Giriama to simultaneously indicate that they 'follow Kaya elders' (kufuata wazee wa Kaya) and to proclaim adherence to the Christian religion (dini). These varying attitudes toward Giriama tradition demonstrate that the status of Giriama Traditionalism as a religion (dini) is also widely contested among Giriama themselves.

10 Scholarly conceptualizations of ATR (in the singular) arguably also run the risk of taking religious boundaries for granted by treating ATR and other religions such as Christianity and Islam as systematic philosophies that are similar but distinct and thus comparable to each other.

11 The cICC website confirms that the organization envisions holy scriptures to be a primary mediator of divine knowledge and wisdom; see: http://cicckenya.org/index.php/about -cicc/core-values-beliefs.

This slogan was used on CICC's facebook banner, posted on 23 March 2019. See https:// www.facebook.com/CoastInterfaithCouncilOfClericsTrust/photos/a.546302715407770/ $2314811568556867 /$ ?type $=3 \&$ theater.

These are described by Parkin (1972, 1991), McIntosh (2005b), and Udvardy (2013).

14 McIntosh $\left(2005 \mathrm{~b}, 55^{-} 57\right)$ argues that the rising costs of living, poverty, and sex tourism increasingly place strains on traditional Giriama socioeconomic arrangements, making Giriama patriarchal structures in which sexual behaviour is strictly regulated difficult to enforce.

15 This elder's choice of the term utamaduni rather than, for example, mila (custom, tradition) is interesting. The term mila has a history of being contrasted to dini, both by Christian missionaries and by reformist-oriented Muslims who seek to keep their religion 
(dini) pure from ('African') customs and tradition (mila) (Middleton 1992, 192). However, the word utamaduni (culture) is an Arabic loanword that has strong connotations to claims of urban modernity and civility, and has been used by Swahili Muslims to contrast their urban civility with the condition of the 'bush people' (wanyika) living in the coastal hinterland, which is how the Mijikenda were previously referred to. This elder's use of the term utamaduni while organizing cultural activities in Malindi town can thus be interpreted as an attempt to claim a Giriama civility that belongs to the city and is equal instead of inferior to Islamic urban civility.

16 For example, David Parkin $(1972,38,53,83-84 ; 1991,155)$ notes that many younger Giriama fear the capability of elderly homestead heads to use witchcraft (utsai) against them to keep them in check. Furthermore, elders initiated into the Vaya secret society are often referred to as potential witches (atsai) because people fear that they may use their spiritual powers maliciously (cf. Willis 1993, 45). 